Relations industrielles

Industrial Relations

\title{
A Reader's Comments
}

\section{The Future of the Collective Agreement Act}

Volume 4, numéro 6, février 1949

URI : https://id.erudit.org/iderudit/1023500ar

DOI : https://doi.org/10.7202/1023500ar

Aller au sommaire du numéro

Éditeur(s)

Département des relations industrielles de l’Université Laval

ISSN

0034-379X (imprimé)

1703-8138 (numérique)

Découvrir la revue

Citer cet article

(1949). A Reader's Comments: The Future of the Collective Agreement Act. Relations industrielles / Industrial Relations, 4(6), 59-60.

https://doi.org/10.7202/1023500ar

Tous droits réservés (C Département des relations industrielles de l’Université Laval, 1949
Ce document est protégé par la loi sur le droit d'auteur. L'utilisation des services d'Érudit (y compris la reproduction) est assujettie à sa politique d'utilisation que vous pouvez consulter en ligne.

https://apropos.erudit.org/fr/usagers/politique-dutilisation/ 
The present frame-work of society does not include the working classes. It is unionism which has the mission of intregating these classes into the new limits which are being imposed, and then of teaching them the rights and the duties which derive from their new responsibilities.

It is not then simply a question of appeasing the workers' claims, still less of making use of unionism to consolidate the present position of economic society. Nor is it even a question of putting forward certain formulae which, without a force to control them, far from orientating a!l society towards the pursuit of the common wellbeing, would finish by thansforming the workers themselves into profiteers.

Pius XII, in his discourse to the Catholic Association of Italian Workers, (June 29, 1948) indicates * the lofty aim towards which should tend 》 the !abour movement - « the training of really Christian workers who, excelling equally in the capacity for their art and in religious consciousness, know to bring into harmony the firm protection of their economic interests with the strictest sentiment of justice and with the sincere determination to collaborate with the other classes of society in the Christian renewal of the whole social iife». There is all the program of the Educational Service of the C.C.C.L. On it devolves the duty of maintaining and passing on this really inspiring idea.
This organism responds to a pressing need. The Catholic and national union movement has such a need of earnest leaders, proud of their industrial organization, enlightened as much in their economic as in their social point of view, «living witnesses of a doctrine which does not err », leaders who know where they go and towards what heights unionism should be directed!

The Educational Service of the C.C.C.L. will make it a duty to co-operate with all those who are occupied with labour training, and with adult education. It will need the experience of everybody to attain this end. To-day, it exists itself because it hastens to train more militant syndicalists «who accept only the principles of justice and Christian charity which cost them something 》 according to the phrase of the general secretary of the C.C.C.L., Monsieur Jean Marchand.

Unionism is an element of reform, not of revolt, or of more first-aid for the present economic society. It tends to collaboration with those who compose it. There is the problem as it shou!d be stated. One must be of the movement, not to understand it, but to feel it, not to explain it, but to realize it even while explaining it. That is the reason why the C.C.C.L. determined to inaugurate its own Educationa! Service which will set forth this prob!em and participate in its solution.

\section{A READER'S COMMENTS}

\section{The future of the Collective Agreement Act}

It is always of importance to défine precisely principles and facts. In the field of labour relations the interralationships between these two terms are ordinarily specified and put in concrete form by laws - general or sociological laws and special or codified laws. These general laws become codified only when they have first of all been confirmed by habits or social facts.

The situation in labour relations prior to 1934 was largely elemental. No legislation, or more exactly, an uncertain legislation regulated activities in the field. When the law was adopted it was evident that its principal aim was to popularize the collective agreements with juridical extension. Definite facts had lead to the promulgation of some such measure.

The Legislator had taken into account first of all that competition amongst similar industries constituted the principal obstacle to the spread of collective labour agreements. Faced with union agreement the employer would give voice to the following opinion: «You cannot require me, a particular employer, to submit myself to conditions from which my principal competitor is exempted. Have this agreement signed by all $m y$ competitors at the same time and I will myself accept the collective agreement which you submit to me, thus we will all be on the same footing of equality. 》

To summarize the affair - being given that wages are a constituent element of the cost price, the employer has but to increase his selling price proportionately in order to receive an equivalent value. But to be obliged to increase a cost price when a competitor can leave his at the previous level is to be placed in an inferior competitive position.

The Collective Agreement Act aims at surmounting this obstacle by decreeing the extention of some of the clauses of the collective agreement to similar branches of economic activity on condition that the stipulations have, in the opinion of the Labour Minister, « a preponderant significance and importance.»

An interesting article appearing in the December issue of the \&ulletin des relations industrielles $\gg$ of Laval includes, in my opinion, a too-generalized eulogy of the Collective Agreement Act. Not that the eulogy is not intrinsically earned but that the author seems to want to make of the said law a universal panacea for all the ills inherent in labour relations. We might well bring into consideration the sociological limitations of such a law :

1) The union agreement is the basis of the collective agreement with juridical extension. 
2) The clauses of an agreement, before being extended, should have \& a preponderant significance and importance ».

At once it is evident that the union agreement is the basis of a decree. This latter makes for unity, it, so to speak, imposes a co-ordinating principle. To do this, to make such an adjustment demands time and study. That is why the union organizations in their logical processes request the juridical extension when experience confirms that the extension is practical. A first limitation is then placed by the facts.

The Legislator wanted to leave with the Minister of Labour the authority for applying the decree. Here, prerequisites must be considered before it can be determined that the clauses have \& a preponderant signification and importance. » One of these prerequisites lies in the representative character of the negotiators; it is important that the workers in an industry be organized to a proportion of at least $50 \%$, otherwise it would be a question of imposing the views of a minority.

Juridical extension, of necessity, occasions inevitable delays on the employer's side as well as on the employees' side. And additional delays because it is incumbent upon the employer to prove the preponderance.

Other considerations can be called to the support of these statements. The Labour Relations Act, adopted in 1944, has for primary aim the positive protection of a natural right - the right of association. The Collective Agreement Act, of earlier origin, by its very nature and scope, aims at generalizing the benefits, won by the exercise of the right of association recognized practically only in 1944. The logical priority of the Labour Relations Act is thus clearly demonstrated.

On the other hand, the wage clauses of a decree always impose a minimum in order to preserve the principle of $<$ the preponderant significance $\gg$. This minimum often serves as a basis of discussion for union agreements. To count on the decree to extol a directing principle in employer-employee relations is then to minimize the improvements brought by co-operating legislation.

Finally, let us say that the putting into effect of the decrees has given rise to certain abuses which result not from the default of the principle of the law but from the difficulty of applying such a principle. In the presence of the decree, certain employers have shown an interesting defence reflex. They have attempted to make use of the decree to establish monopolies by using their influence to raise wage rates as much as possible (a thing which appears somewhat strange at first sight).

Of necessity, in a given industry, enterprises have not all the same economic importance. Large enterprises attempt then to raise the minimum as much as possible in order to force out small enterprises by placing them in an economic position where it will be impossible for them to pay the wages decreed. Zoning is not the final remedy for this state of things, not only because it brings back into play a first obstacle, i.e. differentiated wage scales, but also because modern economic activity includes in a given industry, enterprises distributed in an extremely disproportionate manner. The situation would be equalized if it were facing average industries but the juxtaposition of very large and very small enterprises complicates the practical application of the decree when the successful application of the law presupposes a normal economic activity, i.e. a balanced one.

It is right to encourage and advocate the multiplication of collective agreements with juridical extension but it is important to examine their necessarily limited possibilities. In studying it under this angle, one does not wish \& to make the most of the reasons for limiting the field of action of the law as says the author of the article, but simply to place the law in its proper field of action.

Finally, it seems to me an erroneous point of view to believe that one can manage « to search for, and to find the means of extending it (the Collective Agreemen Act) to the whole domain and to all the problems of employeremployee relationships ». The Legislator at the moment is behindhand with the study of a Labour Code. It is not rash to state that such a code cannot include only the improved collective agreement capable of being extended $\ll$ to the whole domain and all the problems of employeremployee relationships $\gg$.

There is no single remedy for the disorders of the social body of to-day. But, a well-rounded and complete legislation should cover all stages and should protect all rights.

\section{Personnel direction in the retail trade}

The Department of Industrial Relations is organizing in cooperation with the Extension Service of the Faculty of Social Sciences, Laval University, an intensive study session to be held from Monday, March 14th., at two o'clock, to Tuesday noon. This series will be on Personnel Direction in the Retail Trade. The program consists of four meetings as follows:

MONDAY, MARCH I4

General Introduction to Personnel Direction, from 2.00 to 3.30 p.m., by Mr. Jean Gagné, B.A., LL.L., M.Soc.Sc., lawyer, professor and secretary, Department of Industrial Relations of Laval University.

The Problems of Personnel Direction in the Retail Trade: Reasons for, organization and functioning of such a service, from 3.30 to 5.00 p.m., by Mr. Jean
Mathieu Cantin, M.Soc.Sc., Director of Personnel, Le Syndicat de Québec Ltée.

Tho role and the function of the Department Head in the Retail Store, from 8.00 to 10.30 p.m., by Mr.

Edouard Coulombe. B.A., General Manager, J.B. Laliberté Ltée, President, Conseil central des Associations patronales de Québec.

TUESDAY, MARCH 15

The administration of the Collective Agreement and the training of Personnel in the Retail Store, from 9.30 to 12.00 a.m., by Mr. Louis Bilodeau, Secretary, Association patronale des Services hospitaliers de l'est de la Province de Québec.

The fees for the course will be $\$ 10.00$ (Monday night's dinner included), and the conferences will be delivered in French. The meetings will take place at: "L'Institut Canadien" building, 37, Ste-Angèle St. Subscription should be sent in by March 8th., at the latest, to: Service extérieur d'éducation sociale, 2 rue de l'Université, Québec. 